\title{
Enam Film Dokumenter dalam Program "Sejarah dan Identitas” Festival Film Papua IV 2021
}

\author{
Michael Don Lopulalan
}

Mahasiswa Antropologi UGM-2017

Email: donlomichael@gmail.com

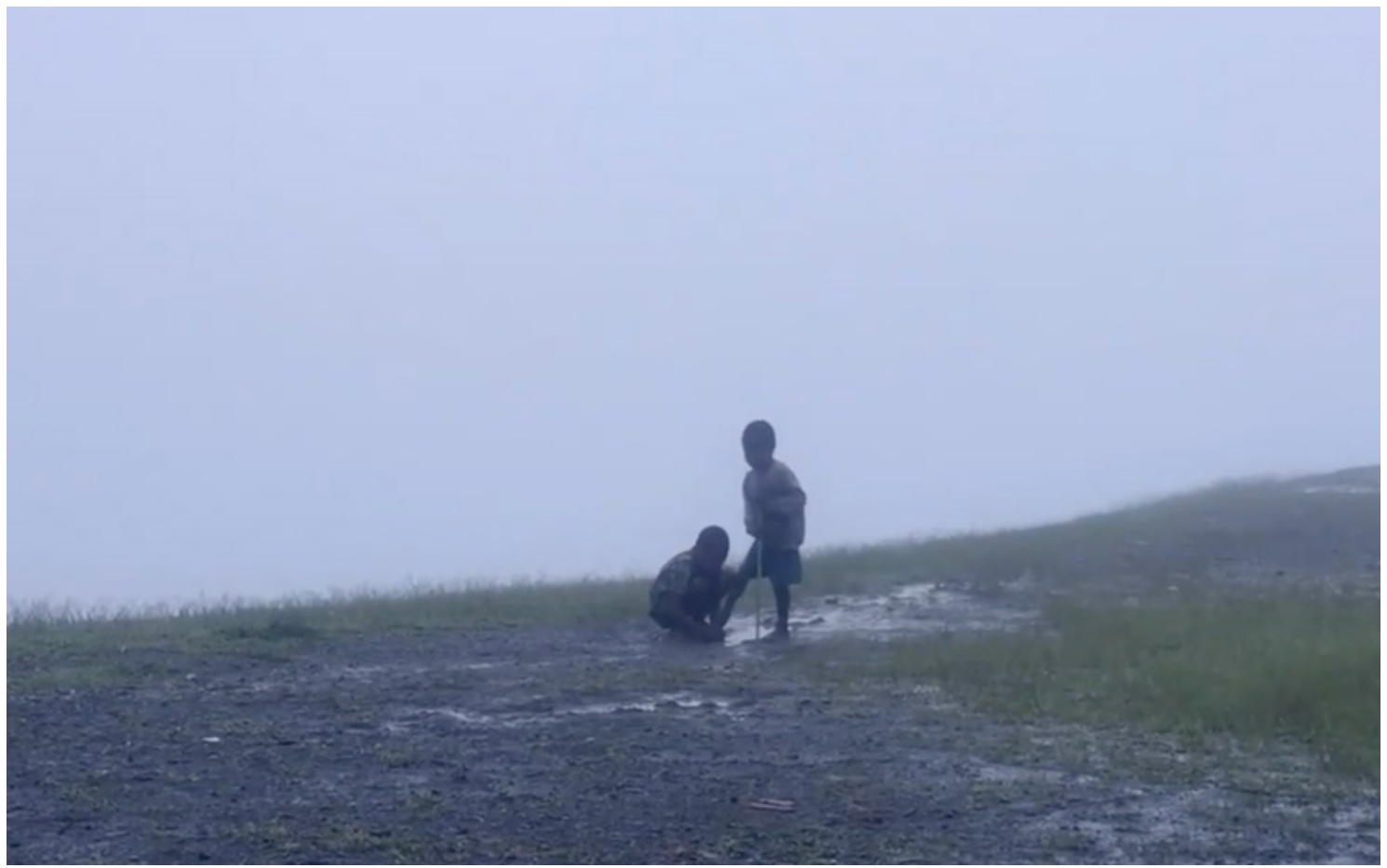

Gambar dari salah satu film, Siklus Hidup (2021)

Pada tahun 2021, Festival Film Papua (FFP) kembali menggelar acaranya, melalui kanal YouTube secara terbatas. Tahun ini, merupakan kali keempat FFP berlangsung. Acara yang sebelumnya dicanangkan untuk dilaksanakan tahun 2020 di Wamena, harus tertunda hingga Agustus 2021 karena pandemi di Indonesia yang tidak kunjung memberi kepastian. FFP menyediakan enam program yang berisi film-film hasil kuratorial. Salah satu program yang dibahas melalui ulasan ini adalah "Sejarah dan Identitas" meliputi enam film dari berbagai daerah di Papua serta mancanegara. 
Dalam ulasan ini, pembahasan film akan dibagi menjadi dua bagian yaitu ulasan masing-masing film untuk memberi gambaran umum tentang isi dan secara rangkaian untuk memberikan konteks relasi antar film yang berada dalam rumpun program FFP. Tujuan penulisan ini, selain meninjau bentuk-bentuk yang disajikan melalui gambar dalam penceritaan identitas, juga menilik posisi film melalui catatan kuratorial yang mempunyai posisinya sendiri sebagai sebuah wadah eksibisi.

\section{Film 1, Kembali ke Jalan Leluhur.}

Harun Rumbarar. 10 menit. Papua: Papuan Voices Keerom, 2020.

Kembali ke Jalan Leluhur mendokumentasi prosesi adat permandian bayi di Suku Abrab, Arso, Keerom, yang kini sudah jarang dilakukan. Kondisi tersebut pula yang menjadi alasan keluarga Salmon Girbes untuk menjalani prosesi untuk anaknya kali ini. Persiapan dilakukan semalam suntuk sampai pelaksanaan yang harus dilakukan ketika matahari terbit. Permandian bayi dilakukan dalam tempo yang sangat singkat karena terjadi pada momen matahari terbit. Prosesi ini menekankan kepada tiga unsur penting yaitu air dan cahaya sebagai nafas hidup untuk bayi serta pemberian anak panah dan busur ukuran kecil sebagai bentuk bekal kehidupan kelak. Prosesi ini tidak hanya mengesahkan bayi tersebut sebagai anak adat namun juga terkandung harapan dan doa sebagai bagian dari anak asli Papua. Diiringi lagu Daiget Yus gubahan Didimus Werare sepanjang durasi dengan repetisi lirik tentang bentuk kehidupan masyarakat Arso zaman dahulu, Harun Rumbarar-dengan nuansa nostalgia-berusaha memotret dan membekukan kegiatan prosesi ini. Kembali ke Jalan Leluhur menunjukkan usaha konservasi adat yang hampir punah meski penonton tidak diberikan pemaparan lebih tentang sebab atau faktor yang membuat prosesi tersebut jarang dilakukan. Visual yang disajikan sudah cukup meski kadangkali level suara yang tidak stabil agak mengganggu pengalaman menonton film.

\section{Film 2, Papua Nahan Makanka.}

Paulus Beali Mahuze. 9 menit. Papua: Papuan Voices Merauke, 2021.

Papua Nahan Makanka berusaha menegaskan pentingnya adat sebagai identitas orang Papua. Paulus lantas memutuskan untuk memakai cutaway shots dalam proses penyuntingan untuk menunjukkan konteks dari narasi "kembali ke adat" yang dituturkan oleh Ruben Awabalek. Sekilas, cara ini memang cukup efektif untuk menjelaskan keadaan Suku Marind untuk mempertahankan adat dan tanah dengan berbagai tantangan dalam perjalanan seperti teknologi, pemahaman anak muda terhadap tradisi, pemerintah, dan pembangunan oleh perusahaan. Untuk mendapatkan konteks terhadap setiap penggalan narasi yang dituturkan tentu saja tidak mudah karena visual yang dihadirkan harus mewakili atau setidaknya menggambarkan keadaan. Hal ini juga tampak menjadi kendala oleh Paulus ketika terlihat kemunculan pengulangan gambar Suku Marind berdoa secara tradisi di depan patung Kristus Raja pada dua konteks narasi berbeda yaitu kembali ke adat sebagai cara hidup yang ada sebelum pemerintah dan agama serta anggapan orang banyak tentang masyarakat Papua yang identik dengan Kristen-meski anggapan ini juga problematis dalam memahami masyarakat Papua Barat (Viartasiwi, et al. 2018). Terlepas dari hal tersebut, menurut saya, film ini cukup untuk menegaskan pentingnya adat sebagai milik setiap suku bangsa yang membentuk suatu manusia sebagai, seperti yang dinyatakan 
oleh Ruben Awabalek, manusia sejati.

\section{Film 3, The Black Orchid.}

Dery Prananda \& Kartika Pratiwi. 11 menit. Australia: The John Darling Fellowship, 2017. The Black Orchid menggarisbawahi penggunaan musik sebagai identitas oleh orangorang asal Papua Barat yang kini sedang tinggal di Australia. Film ini memberi gambaran kegiatan komunitas grup musik The Black Orchid Stringband pada keseharian ataupun saat melakukan penampilan publik di The Melba Spiegeltent, Melbourne. Dery dan Kartika mengeksplorasi kerinduan dan kecintaan para anggota terhadap musik yang menjadi perwujudan atas kehidupan sehari-hari masyarakat Papua Barat sekaligus sebagai kampanye atas identitas Papua di daerah yang asing.

Jawaban para anggota terhadap topik dari peran musik memberikan perspektif baru tentang konstruksi identitas masyarakat Papua yang tidak melulu terbentuk dari adat dan folklor. Kendati terdapat variasi asal daerah Papua Barat pada anggota kelompok yang tentu saja khas dengan adatnya masing-masing, orang-orang ini disatukan oleh memori dan kerinduan yang sama terhadap unsur sederhana dalam kehidupan sehari-hari seperti gurauan, makanan, perjumpaan, dan musik. Film ini tidak mempunyai kekurangan berarti pada gambar dan suara, bahkan, menurut saya, paling rapi dari segi teknis apabila dibandingkan film lain pada program festival ini.

\section{Film 4, Siklus Hidup.}

Yosef Levi \& Tri Arisanti. 30 menit. Papua, 2021.

Siklus Hidup fokus untuk menceritakan penduduk di dataran tinggi Distrik Samenage, Kabupaten Yahukimo melalui kacamata seorang guru, Tri Arisanti. Apabila pada film sebelumnya dari kolaborasi Yosef Levi dan Tri Arisanti dalam Resep Pendidikan Papua (2018) menceritakan tentang praktik pendidikan kontekstual di SDI Saminage, kali ini tuturan lebih mengarah kepada kehidupan masyarakat secara umum. Persiapan tanah yang dipersiapkan oleh para lelaki, pengolahan tanah yang dikerjakan oleh perempuan dan anak, pengangkutan bahan pokok yang diangkat dari pesawat kecil asal Wamena, dan aktivitas sehari-hari anak-anak menjadi topik. Tentu saja, kapabilitas akses Tri Arisanti sebagai guru juga turut berkontribusi terhadap sebagian besar porsi film dengan kegiatan anak-anak di Saminage.

Narasi berbeda dalam sepanjang durasi film juga dibalut pun dijalin dengan indah melalui pemilihan shot statis terhadap kegiatan dan pemandangan serta pemilihan musik, yang meski terulang dan kentara, tampaknya cukup cocok dengan gambar yang dipilih. Kendati tidak ada narasi khusus, frasa dalam judul, yakni siklus hidup, hanya tampak melalui permainan rentetan suara dari tangisan kematian lalu suara bayi yang kemudian ditutup kembali dengan tangisan kematian sedangkan konten filmnya tersendiri lebih cocok dinyatakan sebagai sebuah siklus saja yakni sebagai rentetan kejadian yang berulang terus-menerus. Apabila mengarah kepada cerita tentang siklus hidup, konten yang ada di dalamnya dirasa kurang memenuhi dengan mempertimbangkan bahwa pemahaman yang diberikan perihal kelahiran dan kematian sangat minim dibandingkan rentetan kegiatan repetitif keseharian lainnya. Film ini sangat cocok disaksikan oleh penonton yang tidak begitu ingin masuk terlalu dalam terhadap isu sosial dan lebih memilih untuk menikmati 
menjadi partisipan dan pengamat terhadap keseharian pada satu daerah di dataran tinggi Papua.

\section{Film 5, Saprop Isoine Kapar Kawer.}

Alima M. Inekeb. 14 menit. Papua: Papuan Voices Biak, 2021.

Saprop Isoine Kapar Kawer mempunyai fokus terhadap dua hal yaitu pemahaman masyarakat lokal terhadap hak ulayat tanah dan konflik sengketa tanah adat dari proyek pembangunan. Dua fokus ini terbagi menjadi empat bagian yang secara tegas seperti presentasi dalam tiga wawancara terkait pandangan orang Biak tentang tanah serta satu wawancara terkait tanggapan terhadap isu sengketa tanah adat. Dikarenakan seluruh film tersusun dari rangkaian empat wawancara, film ini sangat berhasil untuk memberikan pengetahuan tentang pemahaman tanah masyarakat Biak berikut isu yang dihadapi pada masa kini. Mulai dari konsep tanah yang terbentuk dari sejarah perang, tanah sebagai tempat terjadinya sistem kehidupan yang tidak terputus, dan tanah sebagai kepemilikan bersama yang bertabrakan dengan ide tentang mata pencaharian, pasar, serta pembangunan sebagai program negara.

Satu bagian yang menurut saya menarik terdapat pada wawancara terakhir dengan Gerad Kafiar, Mananwir Bar Napa, terkait tanggapan warga terhadap pembangunan bandara yang tidak mencapai konklusi tertentu. Gerad hanya menjawab bahwa masalah bukan terletak pada tolak atau terima melainkan pada akar persoalan yang tidak kunjung terselesaikan. Kendati demikian, informan tidak memberikan secara tegas akar persoalan selain dari perasaan pemilik hak ulayat. Hal ini menjadi menarik karena, pertama, pemilik hak ulayat telah ditegaskan pada bagian sebelumnya yaitu milik Tuhan yang dititipkan kepada manusia dan, kedua, intensi Alima yang menutup film dengan nuansa kebingungan dalam momen penolakan. Intensi ini saya pahami sebagai upaya untuk menunjukkan kurangnya kepedulian pihak luar terhadap pengetahuan masyarakat lokal tentang makna tanah dan terdapatnya kontradiksi pada ide tentang "kepemilikan" antara pihak luar dengan masyarakat lokal.

\section{Film 6, Amak Msek.}

Alexander F. X. Tegar Kanath. 19 menit. Papua: Komunitas Rumah Imaji Sorong Selatan, 2021.

Amak Msek mendokumentasikan situs sejarah penginjilan sebagai tonggak awal agama Kristen. Amak Msek merupakan Bahasa Tehit di Sorong Selatan yang berarti batu licin. Istilah ini mengacu kepada tepian pantai yang berupa batu, tempat seorang penginjil pertama kali menginjakkan kakinya dalam sejarah agama Kristen pada Suku Tehit. Kini, daerah tersebut sudah tertutupi pemukiman dan sampah. Dengan memperhatikan keadaan tersebut, film ini selain berperan sebagai dokumentasi juga berupaya mengadvokasi pengembangan daerah Amak Msek. Sebenarnya film ini merupakan salah satu film yang cukup ringan untuk ditonton pun sangat sarat dengan narasi sejarah, tetapi sangat disayangkan kontribusi musik latar yang bertujuan untuk mendukung suasana malah tidak mengimbangi suara informan. Terlebih, tidak seperti tingkat suara dari lagu, suara dari informan tidak stabil dari adegan ke adegan sehingga sangat sulit menerima informasi dari hasil wawancara. 
Film ini memberikan gambaran tentang urgensi penjagaan dan pengembangan tempat bersejarah sebagai salah satu sumber memori kolektif. Ruang publik (pemukiman dan pasar) yang tengah berada dan menutupi Amak Msek sedang diupayakan untuk dibersihkan untuk mengembangkan suatu wacana baru, suatu memori kolektif baru. Dalam Amak Msek tidak hanya berisi memori kolektif untuk membentuk identitas dari sudut pandang Kristen saja, namun juga di dalamnya berisi Perang Eles sebagai peristiwa momentum awal yang menyebabkan pengiriman penginjil pertama pada daerah tersebut. Tidak sekedar upaya untuk mengarah kepada Kristen, tetapi juga upaya mengingat serta mengenang sejarah perjuangan masyarakat lokal dahulu. Disayangkan, Alexander tidak memberikan informasi lebih terkait pandangan masyarakat yang mendiami tempat tersebut terhadap tempat bersejarah itu ataupun alasan pergeseran fungsi menjadi pemukiman dan pasar yang mungkin diliputi atau tidak diliputi oleh kesadaran tertentu. Pertanyaan tersebut juga pasti muncul karena upaya demi upaya yang dicanangkan untuk menjaga tepian pantai tersebut tampak belum menuai dukungan sampai saat ini.

\section{Ulasan Film}

Film yang berada dalam rumpun program "Sejarah dan Identitas" di FFP IV 2021 kali ini menyajikan tema yang menarik dalam memandang kehidupan masyarakat Papua pada unsur-unsur kecil yang penting. Kaliber yang diberikan juga sebenarnya luas yakni berhubungan langsung terhadap pemahaman kehidupan perseorangan dalam daerah tertentu. Tak dapat dipungkiri bahwa film-film di atas, dengan beban yang relatif ringan untuk dipertontonkan, dapat menjadi sumber edukasi bagi pihak yang sekedar tertarik terhadap budaya Papua atau bagi masyarakat Papua tersendiri agar makin sadar pada unsur-unsur budaya terkecil sekitarnya yang punya arti penting.

Persamaan antara sebagian film-film di atas yang memberi nilai kelebihan dan kekurangan adalah kedekatan isu yang diambil dengan pembuat film. Kedekatan ini dapat memberikan rasa intim, tapi pada satu saat juga membuat jarak pada bagian lain, dalam hal ini adalah konteks yang setidaknya memberikan gambaran yang lebih luas terhadap suatu fenomena. Kembali ke Jalan Leluhur mendokumentasikan suatu prosesi yang telah jarang dilakukan, tetapi sepanjang durasi tidak diberikan keterangan tentang pilihan masyarakat lain untuk tidak melaksanakan prosesi tersebut. Hanya terdapat satu bagian yang menyamakan prosesi permandian bayi secara adat setara dengan pembaptisan di Gereja. Lantas, ada atau tidaknya suatu hubungan yang membuat pernyataan penyetaraan ini muncul hanya menggantung begitu saja. Siklus Hidup sebagai sebuah judul juga berada dalam ruang yang begitu besar dengan konten-kontennya yang sangat intim dengan aktivitas anak-anak, terkhusus kegiatan dalam payung pendidikan, sementara argumen yang dibawakan melalui penempatan suara bayi lalu tangis kematian menjadi agak terlepas. Papua Nahan Makanka melalui tahap penyuntingan yang berbeda dengan lainnya tetapi hanya menggunakannya untuk memberi gambaran terhadap narasi yang terlalu luas. "Kalau kita ikut budaya orang lain, kami kehilangan jati diri," dan "pemerintah tidak boleh mengarang adat," tidak diikuti dengan visual yang memberi penjelasan, menggambarkan perasaan, ataupun berfungsi sebagai simbol. Lain soal dalam film Amak Msek dan Saprop Isoine Kapar Kawer yang saling memberi pemahaman satu sama lain. Isu pada Amak Msek tentang situs bersejarah yang ditutupi oleh bangunan hasil aktivitas masyarakat disinggung 
dalam Saprop Isoine Kapar Kawer yang menyatakan perkembangan zaman dan teknologi berdampak terhadap cara penggunaan lahan untuk memenuhi kebutuhan sehari-hari dari mata pencaharian serta pasar. Meskipun tidak memberikan respon secara langsung, Saprop Isoine Kapar Kawer memberikan suatu faktor penyebab pergeseran penggunaan lahan dari suatu monumen menjadi ruang ekonomi. Begitu pula sebaliknya, respon Mananwir Bar Napa pada Saprop Isoine Kapar Kawer yang tidak memberikan jawaban tegas dibantu oleh bagian terakhir Amak Msek sebagai bentuk perjuangan merawat tanah Papua.

Permasalahan tentang identitas dan sejarah, sebagai nama program rangkaian film ini, juga tentu saja menjadi topik utama. Dalam paparannya, FFP IV 2021 menuliskan bahwa program ini dirancang sebagai respon terhadap berbagai pembatasan dan pelanggaran HAM yang akhirnya mereduksi sejarah masyarakat menjadi "memoria passionis". Ditemukannya frasa "memoria passionis" dalam catatan kuratorial sangat menarik karena jelas catatan ini dibentuk bukan untuk menjelaskan posisi film melainkan untuk memaparkan kondisi yang menjadi fokus kurator. Memoria passionis merupakan salah satu bagian penting dalam teologi politik oleh Johann Baptist Metz sebagai "titik awal teologi dalam keberpihakan terhadap korban" (Adiprasetya 2017) atau dalam konteks ini ialah "rentetan peristiwa kemanusiaan (violence)" yang menjadi ingatan kolektif masyarakat Papua (Suryawan 2012). Melalui catatan kuratorial, FFP IV 2021 memosisikan film sebagai usaha alternatif mengenang memori selain daripada kekerasan oleh otoritas negara yang berlangsung tak terhitung lamanya. Identitas dan sejarah, dalam program ini, lantas dapat berarti pembentukan identitas dari memori masyarakat Papua terhadap dirinya sendiri meliputi adat, tanah, sampai aktivitas sehari-hari-bentuk melihat secara 'saya' ("I") daripada 'diri sendiri' (“self”). Dari Kembali ke Jalan Leluhur dengan adat yang hampir hilang, Saprop Isoine Kapar Kawer dengan tanah, serta The Black Orchid dan Siklus Hidup tentang kehidupan sehari-hari.

Sebagai penonton yang hanya mengetahui keadaan daerah Papua dari literatur, film-film di atas menghadirkan pengalaman menonton yang menyenangkan sekaligus tidak begitu mudah. Meski terdapat berbagai kekurangan teknis yang agak menimbulkan gangguan, saya tidak begitu memperdulikannya karena teknis dapat diperbaiki dari waktu ke waktu serta tampaknya bukan menjadi satu poin penting dalam argumentasi festival. Daripada fokus terhadap teknis, festival lebih menggarisbawahi posisi film dalam perjalanan masyarakat Papua sepanjang sejarah. Penonton yang belum mengetahui sama sekali keadaan Papua mungkin muncul perasaan bingung atau aneh ketika menyaksikan film-film yang ditayangkan. Namun, film-film ini juga dapat memantik berbagai pertanyaan yang akhirnya mensukseskan upaya promosi isu-isu sosial masyarakat Papua. Setidaknya, meskipun secara intensi tidak langsung mengarah kepada permasalahan politik, film-film dokumenter di atas merupakan salah satu bentuk kejujuran masyarakat Papua terhadap diri sendiri yang sekaligus ditujukan kepada seluruh masyarakat Indonesia yang ingin mendengarkan suaranya.

\section{Referensi}

Adiprasetya, J. 2017. "Johann Baptist Metz's Memoria Passionis and the Possibility of Political Forgiveness". In Political Theology, 18(3): 233-248.

Inekeb, A.M. 2021. Saprop Isoine Kapar Kawer. 14 menit. Papua: Papuan Voices Biak. 
Kanath, A.F.x. 2021. Amak Msek. 19 menit. Papua: Komunitas Rumah Imaji Sorong Selatan. Levi, Y. 2018. Resep Pendidikan Papua. 30 menit. Jayapura.

Levi, Y., \& Arisanti, T. 2021. Siklus Hidup. 30 menit. Papua.

Mahuze, Paulus B. 2021. Papua Nahan Makanka. 9 menit. Papua: Papuan Voices Merauke. Rumbarar, H. 2020. Kembali ke Jalan Leluhur. 10 menit. Papua: Papuan Voices Keerom.

Suryawan, I.N. 2012. "Dari Memori Passionis ke Foreri: Sejarah Politik Papua 1999-2000”. In Paramita: Historical Studies Journal, 22(2).

Prananda, D. \& Pratiwi, K. 2017. The Black Orchid.11 menit. Australia: The John Darling Fellowship.

Viartasiwi, Nino, T, Agus, dan Hary Y. 2018. “The West Papua Imagined Community: A Bondless Plural Society”. In Sustainable Future for Human Security, edited by B. McLellan, 79-99. 